\title{
Pengaruh Store Atmosphere dan Emosi Positif Konsumen Terhadap Pembelian Impulsif (Studi Kasus Pada Konsumen Giant Hypermarket Pekanbaru)
}

\author{
Zulia Khairani \\ Fakultas Ekonomi Universitas Lancang Kuning \\ Jl. Yos Sudarso KM 8 Rumbai \\ Telp. (0761) 52581 email: khairani.zulia@gmail.com
}

\begin{abstract}
This study aims to analize how much store atmosphere and consumers positive emotions influence to impulse buying on consumer in Giant Hypermarket Pekanbaru.The sample in this study was 100 consumers who shopped at Giant Hypermarket in last 3 months, with the method of sampling incidental and then do an analysis of the data obtained using the analysis of quantitative data include : validity and reliability, the classic assumption test, multiple regression analysis, hypothesis testing via t test, hypothesis testing via $\mathrm{F}$ test, and analysis of the coefficient of determination (R2). The study found that the store atmosphere partially has possitive effect but don't significant to impulse buying, Positif emotion of consumers partially has possitive effect and significant on to Store Atmosphere. Store atmosphere andpositif emotion of consumers simultanly have positif effect and significant on impulse buying.
\end{abstract}

Keywords: Consumer Behavior, Impulse Buying, Store Atmosphere, Possitive Emotion Of Consumer

Di Indonesia menurut Hernawan (2012) konsumen Indonesia memiliki sepuluh karakter unik, salah satunya konsumen Indonesia cenderung pembeliannya impulsif atau tidak terencana.Pernyataan ini didukung oleh studi yang dilakukan The Nielsen Company tentang tren pebelanja di kota-kota besar di Indonesia semakin impulsif (www.tempo.co, 21 Juni 2011).Berdasarkan riset dari Frontier Consulting Group (www.marketing.co.id, 14 Februari 2012) menunjukkan bahwa pembelian impulsif di Indonesia relatif sangat tinggi.Jika dibandingkan dengan Amerika, sekitar 15\% hingga 20\% lebih tinggi di Indonesia.Hal ini juga memperlihatkan bahwa perilaku belanja di Indonesia relatif tidak teratur bila dibandingkan dengan masyarakat Australia. Di Australia lebih dari setengah warganya memiliki pola belanja tertentu seperti berbelanja pada hari dan jam tertentu. Hal ini disebabkan oleh beberapa faktor seperti budaya, tingkat pendidikan, dan tingkat pendapatan yang relatif masih rendah (www.marketing.co.id, 14 Februari 2012).Hasil studi menunjukkan bahwa pembelian impulsif terjadi di toko ritel.
Perkembangan ritel modern di Indonesia dari tahun 2007 hingga 2012 mengalami pertumbuhan rata-rata $17,57 \%$ per tahun. Tercatat bahwa pada tahun pada 2011 jumlah ritel modern mencapai 18.152 gerai yang tersebar di seluruh kota di Indonesia(www.marketing.co.id, 3 Januari 2013). Dalam persaingan bisnis saat ini, terdapat satu peritel modern yang masih mampu mempertahankan eksistensinya dalam kompetensi bisnis ritel yaitu Giant Hypermarket merupakan jaringan toko swalayan yang memiliki banyak cabang di Indonesia. Giant di Indonesia beroperasi dibawah bendera bisnis jaringan ritel raksasa, PT. Hero Supermarket Tbk. yang telah mengadakan aliansi strategis dengan Dairy Farm International pada tahun 1999 dalam bentuk penyertaan saham langsung. Kerjasama antara keduanya ditandai pula dengan bergabungnya beberapa eksekutif Dairy Farm International sebagai mitra untuk memperkuat jajaran manajemen PT. Hero Supermarket Tbk. Hal ini bertujuan untuk memberikan kontribusi berupa pengalaman dan keahlian internasional yang bermanfaat bagi pengetahuan dan 
pemahaman manajemen PT. Hero Supermarket Tbk.

Pada dasarnya tingkah laku manusia dipengaruhi oleh lingkungan sekitarnya. Penciptaan store atmosphere yang baik akan dirasa nyaman oleh konsumen sehingga dapat berpengaruh secara langsung pada emosional konsumen saat berada di dalam gerai. Mendesain suatu lingkungan melalui store atmosphere dapat merangsang persepsi dan emosi konsumen yang pada akhirnya akan berpengaruh pada keputusan pembelian.

Menurut Levy \& Weitz (2004 : 521) pengaruh store atmosphere merupakan kombinasi dari karakteristik fisik toko seperti arsitektur, tata letak, pemajangan warna, pencahayaan, sirkulasi udara, musik serta aroma yang secara menyeluruh akan menciptakan citra dalam benak konsumen. Fam et al. (2011) menjelaskan bahwa semakin lama waktu yang dihabiskan konsumen di dalam gerai akan menimbulkan probabilitas yang semakin tinggi akan terjadinya suatu pembelian.

Kurniawan, dkk (2013) dalam penelitiannya tentang pengaruh promosi dan store atmosphere terhadap impulse buying dengan shopping emotion sebagai variabel intervening studi kasus di matahari department store cabang supermall Surabaya.Jenis penelitian yang digunakan adalah penelitian eksplanatori.Sampel penelitian adalah konsumen Matahari department store cabang supermall Surabaya, yang berjumlah 150 orang.Penelitian ini menggunakan teknik analisis Structural Equation Modeling (SEM). Hasil penelitian menunjukkan bahwa promotion dan store atmosphere berpengaruh terhadap shopping emotion, promotion dan Store Atmosphere berpengaruh terhadap impulse buying, serta shopping emotion berpengaruh terhadap impulse buying

Hasil penelitian Trisna Dewi dan Ketut Giantari (2015)menunjukkan bahwa store atmosphere memiliki pengaruh positif dan signifikan terhadap pembelian impulsif dan emosi positif, serta emosi positif memiliki pengaruh positif dan signifikan terhadap pembelian impulsif. Hasil perhitungan menunjukkan bentuk mediasi parsial yang berarti emosi positif memediasi secara parsial pengaruh store atmosphere terhadap pembelian impulsif.

Marianty, Resti (2015) meneliti tentang pengaruh keterlibatan fashion emosi positif dan kecenderungan konsumsi hedonik terhadap pembelian impulsif yang mana teknik analisis data menggunakan analisis regresi sederhana dan analisis regresi berganda dan uji hipotesis menggunakan t-test dan F-test.Pengolahan data menggunakan SPSS versi 17.00.hasil penelitian menunjukkan bahwa ketertarikan fashion, kecenderungan konsumsi hedonik, emosi positif berpengaruh positif dan signifikan terhadap impuls buying.

Berdasarkan hal tersebut, dapat ditarik hipotesis sebagai berikut, H1: store atmosphere berpengaruh positif dan signifikan terhadap pembelian impulsif, H2 :Emosi Positif konsumen berpengaruh positif dan signifikan terhadap Pembelian Impulsif. H3 :Store atmosphere dan emosi positif konsumen secara simultan berpengaruh positif dan signifikan terhadap pembelian impulsif.

\section{METODE}

Populasi dalam penelitian ini adalah seluruh konsumen Giant Hypermarket di kota Pekanbaru. Metode pengambilan sampel yang digunakan adalah sampling Insidental. Sampling Insidental adalahteknik penentuan sampel berdasarkan kebetulan, yaitu siapa saja yang secara kebetulan/ Insidental bertemu dengan peneliti dapat digunakan sebagai sampel (Sugiyono, 2014 : 67). Syarat responden yaitu konsumen yang pernah berbelanja di Giant Hypermarket dalam 3 bulan terakhir. Menurut Roscoe dalam Sugiyono (2014: 74), ukuran sampel yang layak sesuai dengan penelitian ini yaitu minimal 10 kali dari jumlah variabel yang diteliti. Maka jumlah sampel yang layak dalam penelitian ini yaitu minimal $10 \times 3=30$. Memperhatikan hal ini dan beberapa pertimbangan, maka pada penelitian ini digunakan sampel sebanyak 100 responden 
Di dalam penelitian ini menggunakan analisis kuantitatif dengan alat $\mathrm{Uji}$ regresi berganda. Hasil perhitungan dari skor atau nilai kemudian digunakan dalam analisis statistik yang dilakukan dengan bantuan komputer, menggunakan program SPSS untuk membuktikan hubungan dan pengaruh antar variabel-variabel penelitian. Tahapantahapan yang digunakan untuk menganilisis data yaitu Uji Validitas, uji Reliabilitas, Uji Penyimpangan Asumsi Klasi, Uji Normalitas Uji Multikolinearitas, Uji Heteroskedastisitas. Selanjutnya dilakukan Uji koefisien determinasi $\left(\boldsymbol{R}^{2}\right)$, dan pengujian hipotesis dengan Uji F (secara simultan) dan $\mathrm{Uji}-\mathrm{t}$ (secara parsial).

\section{HASIL}

Bentuk persamaan regresi berganda yang dihasilkan adalah sebagai berikut :

\section{$\mathrm{Y}=9.527+0.039 \mathrm{SA}+0234 \mathrm{EP}+\mathrm{e}$}

Model regresi ini juga dapat menjelaskan variabel yang paling mempengaruhi pembelian impulsif. Variabel bebas terhadap variabel terikat dapat dilihat melalui standardized coefficents nya. Dalam penelitian ini dapat dilihat bahwa variabel yang memiliki pengaruh paling besar adalah emosi positif konsumen dengan standardized coefficents yaitu 0,234

Pada pengujian secara simultan (Uji F) diperoleh $F$ hitung sebesar 3.506 dengan signifikansi sebesar 0,034. Diperoleh F tabel sebesar 2,06. Dengan demikian dapat diketahui $\mathrm{F}$ hitung $>\mathrm{F}$ tabel dengan signifikansi $(0,034<0,05)$, artinya variabel store atmosphere danemosi positif konsumensecara bersama-sama berpengaruh signifikan terhadap variabel pembelian impulsif.

Hasil pengujian pengaruh store atmosphere terhadap pembelian impulsif diperoleh nilai $\mathrm{t}$ hitung 0,340 sedangkan nilai $\mathrm{t}$ tabel pada taraf $\alpha=5 \%$, maka diperoleh $t_{\text {tabel }}$ 1,98. Hasil tersebut menunjukkan bahwa $\mathrm{t}$ hitung $>\mathrm{t}$ tabel $(0,340<1,98)$ dan signifikansi $(0,734>0,05)$ sehingga $\mathrm{H}_{0}$ diterima dan $\mathrm{H}_{1}$ ditolak atau dapat disimpulkan bahwa secara parsial store atmosphere berpengaruh positif dan tidak signifikan terhadap pembelian Jurnal Daya Saing impulsif konsumen Giant Hypermarket Pekanbaru

Hasil pengujian pengaruh emosi positif konsumen terhadap pembelian impulsifdiperoleh nilai $\mathrm{t}$ hitung 2,218 sedangkan nilai $\mathrm{t}$ tabel pada taraf $\alpha=5 \%$, maka diperoleh $\mathrm{t}$ tabel 1,98 . Hasil tersebut menunjukkan bahwa $\mathrm{t}$ hitung $>\mathrm{t}$ tabel $(2,031\rangle$ 1,98) dan signifikansi $(0,04<0,05)$ sehingga $\mathrm{H}_{0}$ ditolak dan $\mathrm{H}_{2}$ diterima atau dapat disimpulkan bahwa secara parsial emosi positif konsumen berpengaruh positif dan signifikan terhadap pembelian impulsif konsumen di Giant Hypermarket Pekanbaru

Nilai koefisien determinasi simultan $\left(\mathrm{R}^{2}\right)$ sebesar 0,067 hal ini dapat diartikan bahwa variabel store atmosphere dan emosi positif konsumen mampu menjelaskan sebesar $6,7 \%$ terhadap pembelian impulsif. Sedangkan sisanya 93,3 \% dijelaskan faktor-faktor lain yang tidak termasuk pada penelitian ini.

\section{PEMBAHASAN}

Dalam penelitian ini ditemukan hasil bahwa store atmosphere secara parsial berpengaruh positif tetapi tidak signifikan terhadap pembelian impulsif konsumen di Giant Hypermarket Pekanbaru. Hasil tersebut berbeda dengan penelitian sebelumnya yang dilakukan Kurniawan,dkk (2013) dimanastore atmosphere memiliki pengaruh positif dan signifikan terhadap pembelian impulsif pada konsumen Matahari Departemen Store Surabaya. Hasil penelitian yang dilakukan Trisna Dewi dkk (2015) juga menemukan bahwa store atmosphere berpengaruh positif dan signifikan terhadap pembelian impulsif. Hal ini dapat terjadi karena indikator-indikator pada variabel store atmosphere yang ada dalam penelitian ini merupakan pernyataan berkaitan dengan store atmosphere secara umum saja dan sudah diterapkan juga oleh ritel-ritel modern lain yang ada di Pekanbaru. Bagi konsumen,faktor differensiasi pada produk maupun jasa merupakan faktor penting yang

p.ISSN: $2407-800 X \quad$ e.ISSN: 2541-4356 
mempengaruhi keputusan pembelian.Syarif dan Mundir (2008) dalam penelitiannya menemukan bahwa differensiasi berpengaruh signifikan terhadap keputusan pembelian flasdisk Kingston.Hal lainnya dimana menurut (Rook, 1985 dalam Hausman, 2010), konsumen yang mengkonsumsi barang atau jasa secara impulsif biasanya tidak mempertimbangkan konsekuensi dari keputusan yang dibuat tersebut.Menurut Schiffman dan Kanuk (2007) pembelian impulsif merupakan keputusan yang emosional atau menurut desakan hati.Emosi dapat menjadi sangat kuat dan kadangkala berlaku sebagai dasar dari motif pembelian yang dominan.

Selanjutnya ditemukan hasil bahwa emosi positif konsumen berpengaruh positif dan sinifikan terhadap pembelian impulsif. Hal ini sesuai dengan penelitian yang dilakukan Trisna Dewi dkk (2015) juga menemukan bahwa emosi positif konsumen terhadap pembelian impulsif di Matahari Departemen Store Duta Plaza Denpasar .Selain itu penelitian kurniawan dkk (2013) juga menemukan ada pengaruh emosi positif konsumen terhadap pembelian impulsif konsumen Matahari Departemen Store Cabaang SuperMall Surabaya. Marianti, resti (2015) juga menemukan adanya pengaruh yang signifikan emosi positih konsumen terhadap impulse buying pada pada seluruh mahasiswa di kota Yogyakarta yang membeli produk fashion.

\section{SIMPULAN}

Dalam penelitian ini ditemukan tetapi tidak signifikan terhadap pembelian impulsif konsumen Giant Hypermarket Pekanbaru, Emosi positif konsumen berpengaruh positif dan signifikan terhadap pembelian impulsif pada konsumen Giant Hypermarket Pekanbaru.Selanjutnya Store atmosphere dan emosi positif konsumen berpengaruh secara positif dan signifikan terhadap pembelian impulsif konsumen Giant Hypermarket Pekanbaru. mempengaruhi secara positif dan signifikan bahwaStore atmosphere berpengaruh positif

\section{DAFTAR RUJUKAN}

Arvinia Herawati., Ari Pradhanawati., dan Reni Shinta Dewi. 2013. Pengaruh Bauran Pemasaran Ritel terhadap Loyalitas Pelanggan melalui Kepuasan Pelanggan pada Konsumen Alfamart di Kecamatan Tembalang Semarang.Diponegoro Journal of Social and Politic, 2(2), pp: $1-9$

Ayu Pragita, Fauzi dan Kumadji. 2013. Pengaruh Store Atmosphere (Suasana Toko) Terhadap Emosi Dan Dampaknya Kepada Keputusan Pembelian. Jurnal Profit Vol.7

Hernawan. 2012. 10 Karakter Unik Konsumen Indonesia. Diakses tanggal 17 Februari 2016 dari http://www.marketing.co.id/

Japarianto, E., dan Sugiharto, S. 2011.Pengaruh Shopping Lifestyle dan Fashion Involvement terhadap Impulse Buying Behavior Masyarakat High Income Surabaya.Jurnal Manajemen Pemasaran, (6)1, pp: 32-41.

Kim, J, 2006, College Students' Apparel Impulse Buying behaviors in Relation To Visual Merchandising, Journal of Service Research. Vol. 8 No. 3

Kotler, Philip. 2009. Manajemen Pemasaran : Jilid I, Edisi Bahasa Indonesia. Jakarta : PT Indeks Kelompok Gramedia

Kotler, Philip. 2009. Manajemen Pemasaran : Jilid II, Edisi Bahasa Indonesia. Jakarta : PT. Indeks Kelompok Gramedia

Kurniawan dan sondang kunto. 2013. Penagaruh promosi dan store atmosphere terhadap impulse buying dengan shoping emotion sebagai 
variabel intervening studi kasus di matahari departement store cabang supermall Surabaya. Jurnal Manajemen Pemasaran Petra Vol 1 No.2 (2013) 1-8

Park, J., and Lennon, S., J. 2006. Psychological and Environmental Antecedents of Impulse Buying Tendency in The Multichanel Shopping Context. Journal of Consumer Marketing, 23(2), pp: 5868

Pattipeilohy, Victor Ringhard., Rofiati., and M. S. Idrus. 2013. The Influence of The Availability of Money and Time, Fashion Involvement, Hedonic Consumtion Tendency and Positive Emotion towards Impulse Buying Behavior in Ambon City. International Journal of Business and Behavioral Sciences.3(8), pp: 36-49

Rachmawati, Veronica. 2009. Hubungan antara Hedonic Shopping Value, Positive Emotion, dan

Schiffman, Leon dan Leslie Lazar Kanuk. 2008. Perilaku Konsumen. Edisi ketujuh. Cetakan keempat. Jakarta: PT Indeks.
Sarwono, S. W. 2012. Pengantar Psikolog Umum. Cetakan ke-4, PT Raja Grafindo Persada, Jakarta

Sugiyono, 2014. Statistika Untuk Penelitian, Alfabeta, Bandung

Trisna Dewi, Giantari. 2015. Peran Emosi Positif Konsumen dalam memediasi store Atmosphere terhadap Pembelian Impulsif (Studi Pada Konsumen Matahari Departemen Store Duta Plaza Denpasar), EJurnal Manajemen Unud, Vol 4, no. 12, 2015

Utami, Christina Whidya. 2008. Strategi Pemasaran Ritel. Jakarta: Indeks

Utami, Christina Whidya. 2010. Manajemen Ritel: Strategi dan Implementasi Operasional Bisnis Ritel Modern di Indonesia. Edisi ke 2. Jakarta: Salemba Empat 2011. Pembelanja Indonesia Makin Impulsif. Diakses tanggal 17 Februari 2016 dari http://www.tempo.co 